\title{
Interactive breastfeeding scale: proposition based on the middle-range theory of nursing
}

\author{
Escala interativa de amamentação: proposição baseada na teoria de médio alcance de enfermagem \\ Escala interactiva de la lactancia materna: propuesta basada en la teoría de medio alcance \\ de enfermería
}

Cristiane Oliveira Nascimento de Souza ${ }^{1}$ Thais Ruchdeschel ${ }^{1}$ Fabiola Zanetti Resende ${ }^{1}$ Franciéle Marabotti Costa Leite ${ }^{1}$ Marcos Antônio Gomes Brandão² Cândida Caniçali Primo ${ }^{1}$

1. Universidade Federal do Espírito Santo. Vitória, ES, Brasil.

2. Universidade Federal do Rio de Janeiro. Rio de Janeiro, RJ, Brasil.

\begin{abstract}
Objective: To propose a tool to evaluate the dynamic interaction between mother-child-environment in breastfeeding, guided by the Interactive Theory of Breastfeeding. Method: A methodological study that carried out a review of the literature to identify the types of scales available and listed the Pasquali's model and the five-point Likert scale as a guide for the construction process of the Interactive Breastfeeding Scale. Results: The scale consists of 58 items and the response options range from 1 to 5 , where 1 means Never, 2 Rarely, 3 Sometimes, 4 Often, and 5 Always. The sum of the item scores ranges from 58 to 290 , the higher the score, the greater the mother-child-environment interaction. Conclusion: The scale may direct clinical practice in the puerperium and puericulture, helping nurses and other professionals in the maternal-infant area to evaluate the factors that influence the dynamic of mother-child-environment interaction in breastfeeding.
\end{abstract}

Keywords: Breastfeeding; Scale; Nursing Theory; Psychometry; Maternal and Child Nursing.

\section{Resumo}

Objetivo: Propor um instrumento para avaliação da interação dinâmica entre mãe-filho-ambiente na amamentação, orientado pela Teoria Interativa de Amamentação. Método: Estudo metodológico que realizou uma revisão de literatura para identificar os tipos de escalas disponíveis e, elencou o modelo de Pasquali e a escala likert de cinco pontos como direcionamento do processo de construção da Escala Interativa de Amamentação. Resultados: A escala é composta por 58 itens e as opções de resposta variam de 1 a 5, onde 1 significa "Nunca"; 2 "Raramente"; 3 "Às vezes"; 4 "Frequentemente" e 5 "Sempre". O somatório das pontuações dos itens varia de 58 a 290; quanto maior a pontuação, maior será a interação mãe-filho-ambiente. Conclusão: A escala poderá direcionar a prática clínica, no puerpério e puericultura, contribuindo para que enfermeiros e outros profissionais da área materno-infantil avaliem os fatores que influenciam na interação dinâmica de mãe-filho-ambiente na amamentação.

Palavras-chave: Amamentação; Escala; Teoria de Enfermagem; Psicometria; Enfermagem Materno-Infantil.

\section{RESUMEN}

Objetivo: Proponer un instrumento para evaluar la interacción dinámica entre madre-niño-ambiente en la lactancia materna, guiado por la Teoría Interactiva de la Lactancia Materna. Método: Estudio metodológico que realizó una revisión de la literatura para identificar los tipos de escalas disponibles y listó el modelo de Pasquali y la escala de likert de cinco puntos como guía para el proceso de construcción de la Escala Interactiva de la Lactancia Materna. Resultados: La escala consiste en 58 elementos y las opciones de respuesta van de 1 a 5 , donde 1 significa nunca, 2 raramente, 3 a veces, 4 a menudo, y 5 siempre. La suma de las puntuaciones de los elementos fluctúa entre 58 y 290, mientras mayor sea la puntuación, mayor será la interacción madre-niño-ambiente. Conclusión: La escala puede direcionar la práctica clínica em el puerperio y puericultura, ayudando a las enfermeras y otros professionales del área materno-infantil a evaluar los factores que influyen en la dinámica interacción madre-niño-ambiente en la lactancia materna.

Palabras clave: Lactancia materna; Escala; Teoría de Enfermería; Psicometría; Enfermería materno-infantil.
Corresponding author:

Cândida Caniçali Primo.

E-mail: candida.primo@ufes.br

Submitted on 01/04/2018.

Accepted on 04/06/2018.

DOI: 10.1590/2177-9465-EAN-2017-0213 


\section{INTRODUCTION}

Breastfeeding is a "process of dynamic interaction in which mother and child interact with each other and the environment to achieve the benefits of human milk offered directly from the breast to the child, a unique experience at each event." Thus, breastfeeding is more than nurturing a child with human milk, it is a complex phenomenon that can undergo biological, psychological, cultural, social, economic and political influences.

Considering the complexity of the phenomenon of breastfeeding and the use or construction of theoretical references, these are alternatives that can make it easier to interpret the relations between phenomena and facts. Given that, the present study takes as an analytical reference the Interactive Theory of Breastfeeding, a middle-range theory, proposed describe, explain, predict and prescript the phenomenon of breastfeeding, examining its antecedent factors, attributes and consequences. ${ }^{1}$

There are a number of global instruments that have been developed and tested to assess some aspects of the breastfeeding process. These instruments involve elements such as maternal confidence, newborn's behavior, mother's behavior, positioning, holding, effective milk extraction, breast aspects, maternal satisfaction, mother's perception, maternal experience, among others. Some of these are better known and validated in different countries, such as: The Infant Breastfeeding Assessment Tool - IBFAT, which is a neonatal behavioral scale on latching and extracting milk along with maternal satisfaction; The Neonatal Oral-Motor Assessment Scale - NOMAS, which identifies and quantifies oral-motor behaviors in preterm and regular-term newborns; The Preterm Infant Breastfeeding Behavior Scale - PIBBS, which evaluates the neonatal behaviors in breastfeeding related to the development of the stomatognathic and orofacial system; The Systematic Assessment of the Infant at Breast (SAIB), composed of a check list to evaluate the contribution of the newborn at term to breastfeeding (neonatal biological conditions); The Mother-Baby Assessment - MBA, which evaluates five maternal and five infant behaviors related to handling, positioning, the beginning and the end of the feeding. ${ }^{2}$ Furthermore, The Breastfeeding Evaluation and Education Tool BEET, which is an instrument that assesses maternal behavior and experience, neonatal health status, and the position and attachment of the mother-baby binomial. The form, Breastfeed Observation Form - BREAST, looks at the baby's attitudes and effective nutrition correlated with the maternal relationship and its biological condition. ${ }^{3}$

In Brazil we use the Canadian Breastfeeding Self-Efficacy Scale (BSES), which has been translated and adapted to the Brazilian cultural and grammatical reality, with a correlation between the efficacy of breastfeeding and the woman's confidence. ${ }^{4}$ The observation and breastfeeding evaluation of the United Nations Children's Fund (UNICEF) $;{ }^{5}$ and the Instrument for the Evaluation of Early Premature Infant Feeding Readiness, which was developed and validated by Brazilian researchers, could contribute to the evaluation of the premature when it comes to the best time to initiate breastfeeding in a safe and objective way. ${ }^{6}$

A series of measurable scales of the most diverse aspects are available, however, because it is a process of dynamic interaction between mother-child-environment. These instruments do not seem to evaluate the interaction element during the breastfeeding process. Thus, the present study aims to propose an instrument to evaluate the dynamic interaction between mother-child-environment in breastfeeding, guided by the Interactive Theory of Breastfeeding. ${ }^{1}$

\section{METHOD}

Methodological study, carried out in two stages. At first, an integrative literature review was carried out to identify the types of scales available. The guiding question of this review was: What are the types of measuring scales available in the literature? The bibliographic survey was carried out on the internet in the databases: LILACS (Latin-American and Caribbean System on Health Sciences Information), MEDLINE (Medical Literature Analysis and Retrieval System online), Psychology Index (Technical-Scientific Journals), BDENF (Nursing Database), with descriptors: scales; psychometry; validation studies; construction; validity of the tests with the cross-referencing of the two-by-two descriptors.

As inclusion criteria for the selection of the sample we used: articles published in Portuguese, English and Spanish, with abstracts available, with no specific period determined. Exclusion criteria: articles that did not describe the steps for the elaboration of psychometric instruments.

Subsequently, the scale of evaluation of the dynamic interaction between mother-child-environment during breastfeeding was elaborated, following Pasquali's model, ${ }^{7,8}$ for the construction of the psychometric scale, which is based on three major procedures or poles: I - Theoretical Procedures; II - Empirical Procedures; III - Analytical Procedures. Pasquali's model ${ }^{7}$ will be described below with emphasis on Theoretical Procedures in the construction of psychometric instruments.

Theoretical Procedures: this pole focuses on the theory that should support any scientific project. It dimensions the construct, incorporating components of the structure of the concepts for conceptual clarification and for the accuracy of the construction of items. The theoretical pole is subdivided into 6 (six) steps: 1 Psychological system: aims to establish the construct, represents the object of interest; 2 - Characterization: consists of defining the properties or attributes that characterize the construct; 3 Dimensionality: it refers to the internal and semantic structure of the construct, being able to have a unifactorial or multifactorial configuration; 4 - Definition: detailed conceptualization of the construct; 5 - Operationalization: construction of the items that will integrate the measuring instrument, which has 3 stages: 5.1 - Source of the items; 5.2 - Construction rules of items and 5.3 - Quantity of items; and 6 - Theoretical analysis of the items. ${ }^{7,8}$ 
As for the rules of construction of the items, they must be applied for each item, and in some types of items some of these rules may not be applied. Pasquali ${ }^{8}$ recommends the application of a set of twelve rules or criteria, with the first ten rules directed to the construction of the items and the last two oriented to the instrument itself.

A reasonable number of items may be required to fully reach or cover the greater portion of the semantic extension of a construct. A good practice properly guided proposes that a construct needs approximately 20 items to be adequately represented. For those constructs of greater simplicity, we must consider a smaller number of items, six or less items. However, most part of latent features tend to have greater diversity of aspects and need to use a larger number of items. According to the perspective of traditional positivist psychometry ${ }^{7}$ the guarantee of a final instrument version with a reasonable number of items depends on starting with at least three times the quantity of items desired, in order to reach the appropriate number by the end.

The last stage of Theoretical Procedures is the theoretical analysis of the items, which consists in requesting other opinions on the items already formulated. In this stage, we perform: semantic analysis, which seeks to examine whether the whole population understands the proposed items, from the lowest stratum to the sphere of greatest ability, and the content validity analysis of the items, for verification by experts, if the items refer to the object of study. In this study we performed steps 1 to 5 regarding the Theoretical Procedures. The project was approved by the Ethics and Research Committee under the Certificate of Presentation for Ethical Consideration (Comitê de Ética e Pesquisa sob CAAE) ํㅜ 53610316.8.0000.5060.

\section{RESULTS}

In the literature review on the types of available scales, 106 articles were found, with 26 duplicated, totalling a sample of 80 articles. After reading the articles, many models of psychometric scales were identified. Among them, the most known are the Likert scales, the Thurstone scale, the Guttman scale and the Phrase Completion Scale..$^{9,10}$

According to Pasquali, ${ }^{8}$ psychometry seeks to clarify the meaning of the responses attributed by people to a group of tasks, typically called items. In sciences, it is common to use measuring instruments to measure the object of study. Adequate instruments need to be developed so that the measures are effective and demonstrate the reflection of the reality studied in a reliable way. ${ }^{11}$

The Thurstone scale was created in 1929 by Thurstone and Chave, focusing on the objective selection of sentences where respondents have to express their agreement or disagreement. Each item receives a value, and based on the weighted average of the items, as agreed, we measure the response..$^{9,12}$
In 1932, Rensis Likert created a five-point scale. The study of this author advocates the construction of scales that allow people from different points of view to respond to the questionnaire. Likert considered an odd number of points per item so that the neutrality of opinion is at the center point and the points at the ends are opposite and symmetrical. ${ }^{9,11}$

The Guttman Scale was first presented in 1944. It was also constituted by items where the respondent should give an opinion on agreement or disagreement. However, these items have a hierarchical order, in where the ordering follows the orientation from the least favorable to the most favorable. Although extremely useful as measures of attitudes, Guttman-type scales are very difficult to construct. ${ }^{9,12}$

The Phrase Completion Scale was created in 2003 by Hodge and Gillespie to overcome the problems of interpretation of the Likert scale. The standard scale has 11 points, where 0 is the absence of attributes and 10 is the maximum intensity of its presence. According to its creators, the format of this scale facilitates the interpretation by the respondent. Nevertheless, this scale presents a great demand for space, making the questionnaire very extensive, prone to errors in the answers. ${ }^{10}$

As far as the Likert scale is concerned, since its inception, it has been widely used because it presents fewer categories of answers, with less difficulty to fill in, which is less complex than the other scales and has an adequate degree of reliability. ${ }^{11}$

Currently, the points of the Likert scale can vary from 3 to more than 10. The most widely used are those of 5 and 7 points. Some authors argue that numbers of points do not influence the internal consistency of the Likert scale, but studies show that a 3-point scale, although easier to apply, has less ability to pinpoint the opinion of the interviewees. The 5-point and 7-point scales demonstrate the same mean accuracy, but the 5-point scale is easier and faster. Specialists state that very complex scales tend to make respondents simplify the task by using heuristics. One of them is called status quo, where the response to be chosen tends to be the same as that selected for the previous item. The use of the status quo may be higher or lower, depending on the cognitive ability of the respondents. ${ }^{8,11}$

The Likert-type scales seek to assess to which extent individuals agree or disagree about an object, phenomenon or other element, and their use is easier, since the subject can indicate as to the agreement or not in relation to any affirmative. , $^{7,10}$

After evaluating the types of scale, the 5-point Likert was chosen to elaborate the instrument (due to the ease of construction and application and speed of use) since studies concluded, through simulation, that in scales with more than 5 points no gain of reliability has been observed. ${ }^{10}$

The results of the Theoretical Procedures (Steps 1-5), which deal with the "Interactive Breastfeeding Scale" proposition, are presented in a scale to investigate the dynamic interaction between mother-child-environment in the breastfeeding process. 
Regarding the first step, psychological system, the object of interest is breastfeeding, and the proposed instrument is based on the Interactive Theory of Breastfeeding. ${ }^{1}$ The theory was elaborated by deduction, from the Imogene King's Conceptual Framework ${ }^{13}$ and based on an inductive process aligned with the literature review to produce scientific evidence. The purpose of the theory is to describe, explain, predict and prescribe breastfeeding, providing elements that constitute antecedents, attributes and consequences of the breastfeeding process. ${ }^{1}$

Many psychometric instruments do not use theories as guidelines in the construction of scales, influencing the production of psychometric instruments with limitations. One of the reasons for this limit is related to the absence of an explicit point of the theory used to subsidize the construction of the instrument. Elaborating from the random sample collection of items with face validity is more common, that is, the selection of those items which seem to offer features appropriate to the purposes of the measure. ${ }^{8}$

As for the "Characterization" step, in which the attributes of the phenomenon of interest must be defined, in the Interactive Theory of Breastfeeding the critical attribute of breastfeeding is the dynamic interaction between mother and child. This dynamic involves perception, judgment, action and reaction between mother and child during the mother-child latching and extracting milk, to achieve the mutual goal, which is breastfeeding. This dynamic interaction is guaranteed by verbal and non-verbal communication that takes place between mother and child. ${ }^{1}$

Communication between mother and child occurs through gestures, touch, posture, facial expression, physical appearance, body movements, as well as verbal elements of the mother, words and sounds, and the child's crying and sounds. ${ }^{14-16}$

In the "Dimensionality" step, we observe that the breastfeeding phenomenon is a multifactorial construct, being influenced in the Interactive Theory by the following factors: woman's and child's biological conditions; woman's and child's perception; woman's body image; space for breastfeeding; mother's role; organizational systems for the protection, promotion and support of breastfeeding; family and social authority; woman's decision making; and mother-child dynamic interaction. ${ }^{1}$

Regarding the "Definition" step, the Interactive Theory defines breastfeeding as: "breastfeeding is a process of dynamic interaction in which mother and child interact with each other and the environment in order to obtain the benefits of mother's milk, which is directly provided from the breast to the child, a unique experience every time"."

As for the step "Operationalization", the items used were: Interactive Theory of Breastfeeding, ${ }^{1}$ Breastfeeding Self-Efficacy Scale (BSES) ${ }^{4}$ and Breastfeeding Motivational Measurement Scale (BMMS) $;{ }^{17}$ and Observation Form and Breastfeeding Assessment by the World Health Organization (WHO) and the United Nations Children's Fund (UNICEF). ${ }^{5}$
Furthermore, considering "Operationalization" in relation to the criteria for constructing the items, we sought to follow the rules proposed by Pasquali ${ }^{8}$ and all the sentences were written in the affirmative form. Response options range from 1 to 5 , where 1 means "Never"; 2 "Rarely"; 3 "Sometimes"; 4 "Often" and 5 "Always". The sum of the item scores ranges from 58 to 290; the higher the score, the greater the motherchild-environment interaction in breastfeeding. When the points indicate low mother-child-environment interaction it is possible to target interventions for a given area in order to be successful in breastfeeding.

Items in which the questions indicate the absence of mother-child-environment interaction, "Always" and "Never", are given values of 1 and 5 , respectively. The order of values is reversed for items 18, 20, 23, 27, 32, 34, 36, 38, 40, 42, 44, 47 and 49 in which the questions indicate absence of mother-childenvironment interaction. In the rest, "Always" is evaluated as 5 and "Never" is set to 1 .

We emphasize that some questions have assertive negative aspects regarding mother-child-environment interaction in breastfeeding to verify some inconsistency if the interviewee points to boxes 4 or 5 from the beginning to the end of the instrument. That is, the questions that indicate absence of mother-child-environment interaction, when punctuating and producing the coefficient, reverse the response in the punctuation, as explained.

As for the quantity in the instrument, 98 items were elaborated, and after a thorough reading of the concepts, a previous classification was made. Several items were removed or modified, and 58 remained, according to Table 1.

\section{DISCUSSION}

The Interactive Theory of Breastfeeding ${ }^{1}$ is the "T" element of the C-T-E (Conceptual-theoretical-empirical) model, ${ }^{18}$ derived from the Open Systems of King (1981) ${ }^{13}$ which represent the conceptual component or the "component C". Moreover, the proposed Interactive Breastfeeding Scale (component E) represents the empirical indicators that express the existence of the concept itself. They are used to measure the concept because the definition and attributes of breastfeeding are themselves abstract and these indicators are needed to provide observable and measurable data of the phenomenon. ${ }^{19}$ Generally speaking, we can point out some empirical indicators: eye-to-eye between mother and child, communication between mother-child, mother-child position, holding and suckling of the newborn, crying and sleep of the child after feeding, satisfaction report of the mother, productive relations between father-motherson, supply of human milk, emptying of the breast after feeding, among others.

By adopting the multidimensions involved in the conceptual structure of the Interactive Theory of Breastfeeding, the 
Table 1. Relations between the concepts of the Interactive Theory of Breastfeeding and the items of the Interactive Breastfeeding Scale.

\begin{tabular}{|c|c|c|c|c|c|c|}
\hline $\begin{array}{l}\text { Concepts of the } \\
\text { Interactive Theory } \\
\text { of Breastfeeding }\end{array}$ & Interactive Breastfeeding Scale & Never & Rarely & Sometimes & Often & Always \\
\hline \multirow{21}{*}{ Women's Perception } & 1. I correctly place my baby on my breast. & & & & & \\
\hline & $\begin{array}{l}\text { 2. I feel satisfaction when my baby is satisfied } \\
\text { after breastfeeding. }\end{array}$ & & & & & \\
\hline & $\begin{array}{l}\text { 3. I talk to and look at my baby while } \\
\text { breastfeeding. }\end{array}$ & & & & & \\
\hline & $\begin{array}{l}\text { 4. My baby is calm and relaxed after } \\
\text { breastfeeding. }\end{array}$ & & & & & \\
\hline & 5. I feel relaxed and comfortable to breastfeed. & & & & & \\
\hline & 6. I can correctly place my baby on my breast. & & & & & \\
\hline & 7. I can correctly hold my baby to breastfeed. & & & & & \\
\hline & $\begin{array}{l}\text { 8. I can hold my baby with their head facing my } \\
\text { breast and their body next to mine. }\end{array}$ & & & & & \\
\hline & $\begin{array}{l}\text { 9. I can explain the benefits of breastfeeding for } \\
\text { the health of children. }\end{array}$ & & & & & \\
\hline & $\begin{array}{l}\text { 10. I can explain the benefits of breastfeeding for } \\
\text { the health of women. }\end{array}$ & & & & & \\
\hline & $\begin{array}{l}\text { 11. I believe that the use of pacifiers is harmful } \\
\text { to/hinders breastfeeding. }\end{array}$ & & & & & \\
\hline & $\begin{array}{l}\text { 12. I believe that what I eat influences in my milk } \\
\text { production. }\end{array}$ & & & & & \\
\hline & 13. I believe that breast milk nurtures the baby. & & & & & \\
\hline & $\begin{array}{l}\text { 14. I believe that the size of the breasts and } \\
\text { nipples hinders breastfeeding. }\end{array}$ & & & & & \\
\hline & $\begin{array}{l}\text { 15. I believe that the use of baby bottles is } \\
\text { harmful to/hinders breastfeeding. }\end{array}$ & & & & & \\
\hline & $\begin{array}{l}\text { 16. I know the benefits of breastfeeding for the } \\
\text { health of women. }\end{array}$ & & & & & \\
\hline & $\begin{array}{l}\text { 17. I know the benefits of breastfeeding for the } \\
\text { health of children. }\end{array}$ & & & & & \\
\hline & $\begin{array}{l}\text { 18. I believe that breastfeeding takes a lot of } \\
\text { time out of my day. }\end{array}$ & & & & & \\
\hline & $\begin{array}{l}\text { 19. I have positive experiences with } \\
\text { breastfeeding. }\end{array}$ & & & & & \\
\hline & 20. I believe that it is difficult to continue & & & & & \\
\hline & breastfeeding after returning to work/studies. & & & & & \\
\hline
\end{tabular}


Continued Table 1.

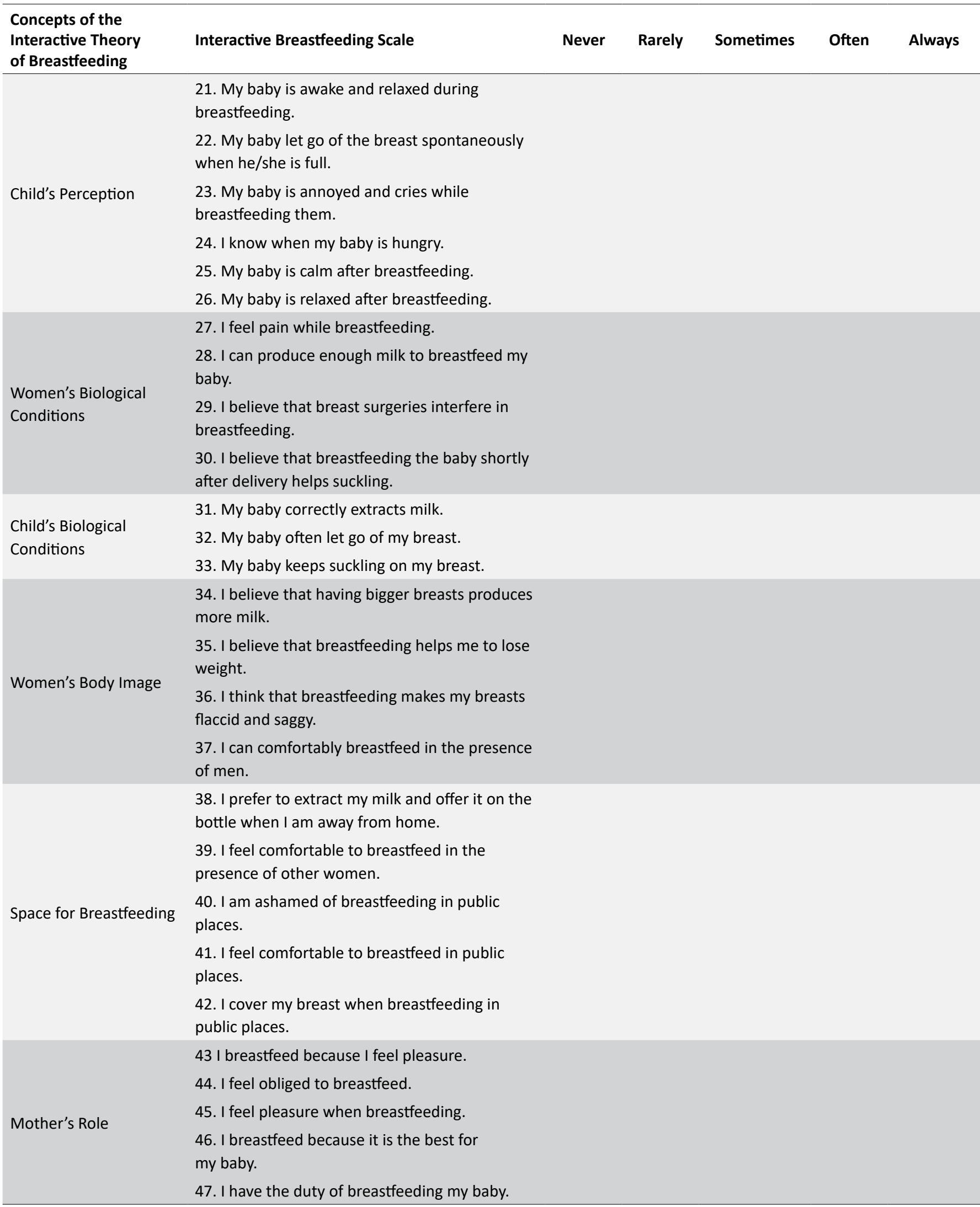




\begin{tabular}{|c|c|c|c|c|c|c|}
\hline $\begin{array}{l}\text { Concepts of the } \\
\text { Interactive Theory } \\
\text { of Breastfeeding }\end{array}$ & Interactive Breastfeeding Scale & Never & Rarely & Sometimes & Often & Always \\
\hline \multirow{5}{*}{$\begin{array}{l}\text { Organizational Systems } \\
\text { for the Protection, } \\
\text { Promotion and Support } \\
\text { of Breastfeeding }\end{array}$} & $\begin{array}{l}\text { 48. I have the support of my family to } \\
\text { breastfeed. }\end{array}$ & & & & & \\
\hline & 49. I need professional support to breastfeed. & & & & & \\
\hline & 50. I have my partner's support to breastfeed. & & & & & \\
\hline & $\begin{array}{l}52 . \text { I believe my community supports } \\
\text { breastfeeding. }\end{array}$ & & & & & \\
\hline & $\begin{array}{l}\text { 53. I use some social support network for } \\
\text { breastfeeding. }\end{array}$ & & & & & \\
\hline \multirow{4}{*}{$\begin{array}{l}\text { Women's Decision } \\
\text { Making }\end{array}$} & 56. I want to breastfeed. & & & & & \\
\hline & 57. I believe that having a positive experience & & & & & \\
\hline & influences my decision to breastfeed. & & & & & \\
\hline & $\begin{array}{l}58 . \text { I think that knowing the advantages of } \\
\text { breastfeeding helps in the decision making to } \\
\text { breastfeed. }\end{array}$ & & & & & \\
\hline
\end{tabular}

phenomenon of breastfeeding is expanded and becomes complex, and it is influenced by personal, interpersonal or social factors of women and children. ${ }^{1}$ Considering that the phenomenon in question is understood as a dynamic process, there are concepts that generate observable empirical referents and others that need to be expressed by women and children. Thus, the scale should be able to grasp indicators that are descriptions, perceptions, and feelings of women who are breastfeeding. Because it is the woman's perception about breastfeeding, a variable aspect established from her knowledge, social and economic conditions, skills, emotions, needs, beliefs, cultures and goals, as well as her life history and individual, family experiences and social interactions with breastfeeding, ${ }^{14,20,21}$ accessing her perception needs to be delineated in items that are referenced in the woman's personal and interpersonal systems and in her beliefs and judgments about the act of breastfeeding.

In addition, the scale must take into account the selfassessment aspects of the women's functional abilities, as well as the mother's inferences about the baby's abilities, which is incorporated in the items referring to the biological conditions of the woman and the child. Such conditions may interfere with breastfeeding and refer to: breasts/nipples of women, milk production, anatomy and physiology of the stomatognathic system of newborns, and diseases/injuries of women and children that may hinder or halt breastfeeding. ${ }^{14,15,21}$
In relation to the social dimensions of breastfeeding, a multidimensional scale such as the proposal must incorporate concepts and empirical referents that have adherence to the mother-child relationship with family, community and society. The Interactive Breastfeeding Scale, when proposing nine items in assertions related to "woman's body image" and "breastfeeding spaces", seeks to contemplate aspects of motherchild-environment interaction, such as, for example, the concern about milk supply, breast tenderness and the embarrassment of breastfeeding in public places. ${ }^{14,20,21}$ The scale recognizes that women, when performing their role as mothers, seek to preserve their autonomy, even if limited, in order to make the decision to start and maintain breastfeeding for her child or not. ${ }^{15}$ For this, the scale presents eight assessment items linked to the "mother's role" and "women's decision making."

In the dimension more characterized as social, the scale adopted the contributions of the literature that defend influences of the social network of the nurse and the interaction of these people with the woman in the process of breastfeeding as essential, since the phenomenon of breastfeeding suffers multiple influences, positive or negative, from family members, friends, neighbors, and health professionals. ${ }^{22}$ The scale also considers the construction of understanding that preparation from gestation with the promotion and support of health professionals is essential to the success of breastfeeding. Considering the nature of the 
scale, the ten items related to "Organizational Systems of Protection, Promotion and Support to Breastfeeding" and Family and Social Authority, also followed the logic of being referenced in the appreciation of the woman who experiences the dynamic process of breastfeeding.

The Interactive Breastfeeding Scale provides designing how the complex concept of breastfeeding can be measured operationally, making explicit the indicators reported by women involved in breastfeeding. We highlight that its greatest contribution probably goes through the scale to be based on a middle-range theory, constructed under a conceptual model of Nursing. Clearly, the authors acknowledge the relevance of multiprofessional practice in the promotion, prevention and support of breastfeeding. Nevertheless, for the improvement of the nursing disciplinary knowledge, theories need to be developed and validated. Notably, the Nursing profession may even advance in a practice not subsidized in nursing theories; this pragmatic advance, however, may not culminate in the delimitation of a cut of elements unique to the knowledge of Nursing.

Finally, we point out that in everyday practice, the adoption of reliable and validated instruments that subsidize the evaluations of the breastfeeding process performed by health professionals is still incipient. Although the studies indicate that face-to-face counselling is paramount to stablish full-time dedication to breastfeeding, it is extremely important to identify at an early stage the possible factors involved in the risk of failure of this process. ${ }^{23}$

\section{FINAL CONSIDERATIONS}

This research carried out steps 1 to 5 of the Theoretical Procedures proposed by Pasquali in the creation of an instrument that evaluates the dynamic mother-child-environment interaction during breastfeeding. The Interactive Breastfeeding Scale, based on the Interactive Theory of Breastfeeding, ${ }^{1}$ is abstract enough to be applicable to all breastfeeding women in different social, cultural, political and economic contexts. In addition, it has provided the authors with contextualized elements of the phenomenon that were sufficient for the creation of a scale for the empirical application of the theory.

This instrument, organized and systematized, has adopted a multidimensional perspective in order to capture the breadth of the breastfeeding process and intends to serve as an instrument to direct clinical practice during the puerperium and child care to help nurses and other professionals in the mother-to-child area to assess the various factors that interfere with the breastfeeding process. By knowing better the individual factors of each client, health professionals can direct, in a safe and competent way, care and guidance provided to the woman-child-family.

Moreover, this research can guide nurses and researchers on how to structure the process of developing an instrument or scale.
Prospective studies using the Interactive Breastfeeding Scale are needed to provide evidence on the validity of the scale, as well as to support the theoretical analysis that the Interactive Theory of Breastfeeding portrays the breastfeeding process. Thus, as a limitation of the study, the scale needs to be submitted to a content validation process by nurses in the area, and then to a clinical validation, when it will be tested with breastfeeding mothers at the outpatient or hospital level.

\section{REFERENCES}

1. Primo CC, Brandão MAG. Interactive Theory of Breastfeeding: creation and application of a middle-range theory. Rev Bras Enferm [Internet]. 2017 Nov/Dec; [cited 2017 Dec 11]; 70(6):1191-8. Available from: http://www.scielo.br/scielo.php?script=sci_arttext\&pid=S003471672017000601191\&Ing=en. DOI: 10.1590/0034-7167-2016-0523

2. Howe TH, Lin KC, Fu CP, Su CT, Hsieh CL. A review of psychometric properties of feeding assessment tools used in neonates. J Obstet Gynecol Neonatal Nurs [Internet]. 2008 May/Jun; [cited 2016 Jun 10]; 37(3):338-49. Available from: https://www.ncbi.nlm.nih.gov/pubmed/?t erm $=\mathrm{Howe}+\mathrm{TH} \% 2 \mathrm{C}+\mathrm{Lin}+\mathrm{KC} \% 2 \mathrm{C}+\mathrm{Fu}+\mathrm{CP} \% 2 \mathrm{C}+\mathrm{Su}+\mathrm{CT} \% 2 \mathrm{C}+\mathrm{H}$ sieh+ $\mathrm{CL}$.+A+review+of+psychometric+properties+of+feeding+assessment +tools+used+in+neonates.+J+Obstet+Gynecol+Neonatal+Nurs. DOI: 10.1111/j.1552-6909.2008.00240.x

3. Moran VH, Dinwoodie K, Bramwell R, Dykes F. A critical analysis of the content of the tools that measure breast-feeding interaction. Midwifery [Internet]. 2000 Dec; [cited 2016 Mar 15]; 16(4):260-8. Available from: https://www.ncbi.nlm.nih.gov/pubmed/11080461. DOI: 10.1054/ midw.2000.0216

4. Oria MOB, Ximenes LB. Tradução e adaptação cultural da Breastfeeding Self-Efficacy Scale para o português. Acta Paul Enferm [Internet] 2010; [cited 2016 Aug 12]; 23(2):230-8. Available from: http://www. scielo.br/scielo.php?pid=S0103-21002010000200013\&script=sci abstract\&tlng=pt. DOI: $10.1590 /$ S0103-21002010000200013

5. Vieira AC, Costa AR, Gomes PG. Boas práticas em aleitamento materno: Aplicação do formulário de observação e avaliação da mamada. Rev Soc Bras Enferm Pediatr [Internet]. 2015; [cited 2016 Nov 5]; 15(1):1320. Available from: http://www.sobep.org.br/revista/images/stories/ pdf-revista/vol15-n1/vol_15_n_2-artigo-de-pesquisa-2.pdf

6. Fujinaga $\mathrm{Cl}$, Moraes SA, Zamberlan-Amorim NE, Castral TC, Scochi CGS. Clinical validation of the preterm oral feeding readiness assessment scale. Rev Latino Am Enferm [Internet]. 2013 Jan/Feb; [cited 2016 Aug 4]; 21 (no.esp):140-5. Available from: http://www.scielo. $\mathrm{br} / \mathrm{scielo}$.php?script=sci_arttext\&pid=S0104-11692013000700018. DOI: 10.1590/S0104-11692013000700018

7. Pasquali L. Psicometria:Teoria dos testes na psicologia e na educação. $5^{\mathrm{a}}$ ed. Petrópolis: Vozes; 2013.

8. Pasquali L. Psicometria. Rev Esc Enferm USP [Internet]. 2009; [cited 2016 Nov 25]; 43(no.esp):992-9. Available from: http://www. scielo.br/pdf/reeusp/v43nspe/a02v43ns.pdf. DOI: 10.1590/S008062342009000500002

9. Curado MAS, Teles J, Marôco J. Analysis of variables that are not directly observable: influence on decision-making during the research process. Rev Esc Enferm USP [Internet]. 2014 Feb; [cited 2016 Jul 10]; 48(1):146-52. Available from: http://www.scielo.br/scielo. php?script $=$ sci_arttext\&pid $=S 0080-62342014000100146$. DOI: 10.1590/S0080-623420140000100019

10. Silva Júnior SD, Costa FJ. Mensuração e Escalas de Verificação: uma análise comparativa das escalas de Likert e Phrase Completion. PMKT - Rev Bras Pesq Marketing, Opinião e Mídia [Internet]. 2014 [cited 2016 Mar 24]; 7(1). Available from: http://sistema.semead.com. br/17semead/resultado/trabalhosPDF/1012.pdf 
11. Dalmoro M, Vieira KM. Dilemas na construção de escalas tipo likert: 0 número de itens e a disposição influenciam nos resultados? Rev Gest Organiz [Internet]. 2013; [cited 2016 Mar 24]; 6(3):161-74. Available from: http://bell.unochapeco.edu.br/revistas/index.php/rgo/article/ view/1386/1184

12. Cunha LMA. Modelos Rasch e Escalas de Likerte Thurstone na medição de atitudes [Dissertação]. Lisboa (PT): Universidade de Lisboa; 2007.

13. King IM. A theory for nursing: systems, concepts, process. New York: Delmar Publishers; 1981.

14. Boucher CA, Brazal PM, Graham-Certosini C, Carnaghan-Sherrard $\mathrm{K}$, Feeley N. Mother's breastfeeding experiences in the NICU. Neonatal Network [Internet]. 2011; [cited 2016 Jun 30]; p. 21-8. Available from: http://www.ingentaconnect.com/content/springer/ jnn/2011/00000030/00000001/art00004. DOI: 10.1891/07300832.30.1.21

15. Lööf-Johanson M, Foldevi M, Rudebeck CE. Breastfeeding as a specific value in women's lives: the experiences and decisions of breastfeeding women. Breastfeed Med [Internet]. 2013 Feb; [cited 2016 Aug 10]; 8(1):38-44. Available from: https://www.ncbi.nlm.nih.gov/ pubmed/23131095. DOI: 10.1089/bfm.2012.0008.

16. Brown A, Arnott B. Breastfeeding duration and early parenting behaviour: the importance of an infant-led, responsive style. PLoS One [Internet]. 2014; [cited 2016 Sep 16]; 9(2):e83893. Available from: https://www.ncbi.nlm.nih.gov/pubmed/?term=Breastfeeding+duratio $\mathrm{n}+$ and+early+parenting+behaviour\% $3 \mathrm{~A}+$ the+importance+of+an+infa nt-led\%2C+responsive+style. DOI: 10.1371/journal.pone.0083893

17. Stockdale J, Sinclair M, Kernohan G, McCrum-Gardner E, Keller J. Sensitivity of the breastfeeding motivational measurement scale: a known group analysis of first time mothers. PLoS One [Internet]. 2013 [cited 2016 Oct 16]; 8(12):e82976. Available from: https://www.ncbi.nlm. nih.gov/pubmed/?term=Sensitivity+of+the+breastfeeding+motivationa I+measurement+scale\%3A+a+known+group+analysis+of+first+time+ mothers. DOI: 10.1371/journal.pone.0082976

18. Fawcett J. Contemporary Nursing Knowledge: analysis and evaluation of nursing models and theories. 2nd ed. Philadelphia (FA): Davis Company; 2005.

19. Walker LO, Avant KC. Strategies for theory construction in nursing. 4th ed. United States of America: Pearson Prentice Hall; 2005. 227 p.

20. Foley W, Schubert L, Denaro T. Breastfeeding experiences of Aboriginal and Torres Strait Islander mothers in an urban setting in Brisbane. Breastfeed Rev [Internet]. 2013 Nov; [cited 2016 Nov 2]; 21(3):53-61. Available from: https://search.informit.com.au/documentSummary; $\mathrm{dn}=$ 150172931975699;res=IELAPA

21. Tyler L, Kirby R, Rogers C. Infant feeding practices among Sudanese women now living in regional south east Queensland, Australia Breastfeed Rev [Internet]. 2014 Nov; [cited 2016 Oct 25]; 22(3):13-9. Available from: http://connection.ebscohost.com/c/articles/99726364/ infant-feeding-practices-among-sudanese-women-now-living-regionalsouth-east-queensland-australia. DOI: 10.1071/PY01007

22. Primo CC, Dutra PR, Lima EFA, Alvarenga SC, Leite FMC. Redes sociais que apoiam a mulher durante a amamentação. Cogitare Enferm [Internet]. 2015 Apr/Jun; [cited 2016 Oct 25]; 20(2):426-33. Available from: http://revistas.ufpr.br/cogitare/article/view/37453/25554

23. Ingram J, Johnson D, Copeland M, Churchill C, Taylor H. The development of a new breastfeeding assessment tool and the relationship with breastfeeding self-efficacy. Midwifery [Internet]. 2015 Jan; [cited 2016 Nov 3]; 31(1):132-7. Available from: http://www.ncbi.nlm. nih.gov/pmc/articles/PMC4275601/.DOI: 10.1016/j.midw.2014.07.001 